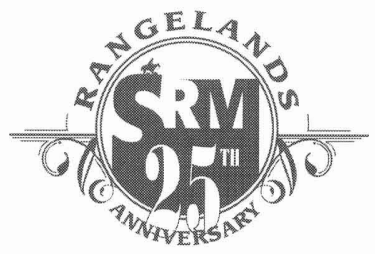

\title{
People From The Past John W. Bohning
}

Editor's Note: As we commemorate the $25^{\text {th }}$ Anniversary of Rangelands magazine, we pay tribute to SRM members who have helped shape the profession of rangeland management.

\section{By Kindra Gordon}

John "Jack" W. Bohning has been a member of

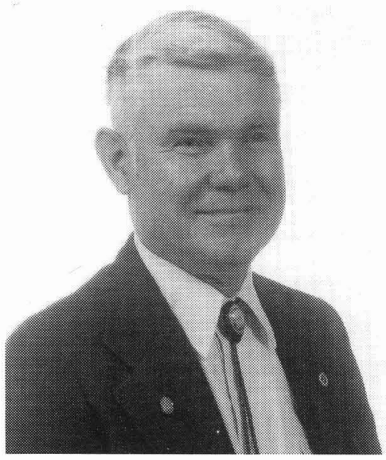
the Society for Range Management since the early 1950 's, and says he joined the organization because of the influence of SRM members with whom he worked.

Bohning's career history focused on range management positions in the U.S. Forest Service, as well as serving as Air

Attack Boss on large fires. He began his college education at Washington State University, left it to go into the service, then went to the University of Idaho in 1946 and graduated in 1948.

Bohning retired as range and wildlife staff on the Prescott National Forest. Currently, he works as a volunteer with the Conservation Education Committee of the Natural Resources Conservation Service (NRCS).

Over the past 50 years, Bohning has been involved in both section and Society committees, Boards of Directors and served as President of the Arizona Section as well as SRM President in 1982.

He recognizes former SRM Executive Vice President Pete Jackson with being a strong influence in setting the management direction for SRM issues and affairs. Bohning recalls a fireside discussion he and Pete had one night at an InternationalMountain meeting in Alberta. From that discussion, Pete submitted an application for the position with SRM and was favorably received by the SRM Board. "Pete's wide variety of experience stood the SRM in good stead," Bohning says.
Bohning credits the Rangelands magazine with being a publication that promoted an exchange of information among technicians and challenges in the field, as well as an opportunity to exchange ideas and philosophies among international members. He says, "Rangelands provided a publishing outlet for budding writers. It also provides the glue to hold members together, and I hope it continues to be the meeting place for all interested parties."

Bohning counts intervention of non-qualified interests seeking legislative solutions to technical problems as one of the greatest natural resource challenges during the past 25 years.

But, a positive change during the history of SRM has been the acceptance of the Society as a knowledgeable entity, says Bohning. Agencies and organizations are seeking SRM input rather than the SRM acting in response to issues, and that's the role SRM should serve, he says.

His advice to future generations studying rangeland management is this: "Look for broad horizons in employment. Many rangeland employment opportunities now exist in the private sector. Don't wrap yourself up in a single agency or cause."

Jack Bohning now lives in Prescott, Arizona with his wife Arline. The couple was married in 1945 and have been blessed with five daughters who live from coast to coast. Bohning says, "We enjoy visiting them and our five grandsons, one granddaughter, one great grandson and one great granddaughter." 